\title{
From Health Crisis to Financial Distress
}

\section{Carmen M. Reinhart ${ }^{1}$ (D)}

Published online: 28 January 2022

(c) International Monetary Fund 2022

\begin{abstract}
I discuss the multifaceted economic and financial vulnerabilities that have been created or exacerbated by the COVID-19 pandemic on a foundation of already weak economic fundamentals in many countries. Crises often do not travel alone. Banking, sovereign debt, exchange rate crashes, sudden stops, inflation often intersect to become severe conglomerate crises. Historically, whether of the individual or conglomerate variety, crises influence the shape and speed of economic recovery. As the health crisis morphs into a financial or debt crisis in some countries, I discuss what may lie ahead in terms of the stages in crisis resolution and brief reflection how the resolution process can be expedited.
\end{abstract}

JEL Classification F3 $\cdot$ F4 $\cdot$ G01 $\cdot \mathrm{N} 1 \cdot \mathrm{N} 2$

It is a real honor to deliver the Mundell-Fleming lecture. Robert Mundell was my thesis advisor, and I have many fond memories of our long discussions during that process. Bob has not only shaped our profession's thinking of open-economy macroeconomics directly but also through his students. Almost 20 years ago, when I was at the IMF Research Department, the second Mundell-Fleming lecture was delivered by Ken Rogoff to honor Rudy Dornbusch, his mentor, who was, in turn, Bob Mundell's student. Rudy was someone who many of us respected and loved; we wish he could be here to share his wisdom at a moment like the one we're going through.

My written remarks proceed as follows. The first section discusses the multifaceted economic and financial vulnerabilities that have been created or exacerbated by the COVID-19 pandemic on a foundation of already weak economic fundamentals in many countries. In the second section, I provide a brief catalog of crises

\footnotetext{
These remarks were prepared for the Mundell-Fleming Lecture at the International Monetary Fund's 21st Jaques Polak Annual Research Conference Living in the Extreme: Economics of Pandemics, Climate Change and Tail Risk, November 5-6, 2020. I would like to thank Vincent Reinhart for useful discussions and comments.
}

Carmen M. Reinhart creinhart@worldbank.org

1 The World Bank, Washington, DC, USA 
(banking, sovereign debt, inflation, sudden stops, etc.) with an emphasis on the fact that, historically, some of these crises often intersect into severe conglomerate crises. Section 3 is focused on how crises influenced the shape and speed of economic recovery. I speculate how they may again do so. As the health crisis morphs into a financial or debt crisis in some countries, I discuss what may lie ahead in terms of the stages in crisis resolution in Sect. 4.

\section{The Setting: Mounting Risks}

Pandemics do occur, although severe ones are rare. Still, I am not aware of a historical episode that can provide any insight as to the likely economic consequences of the global coronavirus crisis. This time truly is different. A feature of this episode that makes it unique is the policy response. Governments around the world have given priority to measures that limit the spread of disease and save lives through extensive lockdowns, strict international travel bans, and the prohibition of all manner of public events.

These measures could not be further from the policy response to the deadliest viral outbreak of modern times, the 1918-1920 Spanish influenza. ${ }^{1}$ That pandemic, which claimed at least 50 million worldwide, occurred against the backdrop of World War I. This fact alone precludes drawing meaningful comparisons regarding the effects of the COVID-19 pandemic per se on the global economy. In fact, in 1918, the year in which influenza deaths peaked in the US, real GDP (driven by wartime activity) rose 9\%. By contrast, as shown in Fig. 1, the October 2020 World Economic Report (WEO) shows 183 countries out of 197 covered (95\%) and including the US are estimated to have had a contraction in real per capita GDP in 2020. In many cases, these were record-shattering declines.

This synchronicity is uncommon. True, financial and sovereign debt crises engulfed the developing world in the early 1980s, while the global economy suffered a deep recession. By 1983, however, the US and other advanced economies were enjoying a robust recovery coupled with lower inflation rates even as many EMDEs were entering their own "lost decade." By contrast, the "Global" Financial Crisis (GFC) of 2007-2009 primarily affected the advanced economies. As the US and Europe slipped into recession, China grew vigorously and lifted global commodity prices, boosting growth in emerging markets and developing economies (EMDEs). China's surging overseas lending to many EMDEs further supported economic activity and facilitated $\mathrm{V}$-shaped economic recoveries following the global turbulence of late 2008 -early $2009 .^{2}$ To find peacetime parallels to the cross-country synchronicity and global economic effects of COVID-19, one has to extend the search back to the 1930 s.

\footnotetext{
1 See Barry (2009) for an excellent account of this episode and the government response.

${ }^{2}$ Horn, Reinhart, and Trebesch (2019) document the surge in China's lending to EMDEs during this period. They also draw parallels to the boom in lending by US commercial banks in the late 1970s that ushered in the debt crises of the 1980s.
} 
While the coronavirus crisis did not start as a financial crisis, it may well be morphing into one. The headlines of the year have been dominated by news of the pandemic's spread, output collapses, and surges in poverty and the newly unemployed. ${ }^{3}$ Behind these disturbing trends a quieter financial balance-sheet crisis is gathering momentum across a broad swath of countries. The financial fallout from the pandemic, in principle, does not respect differences by region or income status, but middle-to-low-income countries are proving especially vulnerable. Scores of financial institutions worldwide are facing and will continue to face for some time a rise in non-performing loans.

Historically, banking crises emerge after a lengthy expansion in economic activity. Growth is often fueled by a credit surge and rising leverage. Under the motto of this time is different, asset price bubbles emerge during the boom (whether in real estate, commodities, equity or bonds varies by episode). As the economic expansion slows and turns into recession, the loans made during prosperous circumstances are looked upon with regret. Sometimes the balance sheet problems undermine confidence and runs on banks and financial institutions turn the crisis into a full-fledged panic. ${ }^{4}$

The runup to COVID-19 does not fit the historical boom-bust pattern, as it is not predicated on mistakes made in a prior economic expansion or an asset price bubble. The common thread is that the historic magnitudes and likely persistence of the downturn in economic activity may expose evolving balance sheet frailties. It is a regressive crisis, within and across countries. Job losses disproportionally hit low-income households and smaller firms that have fewer assets to avert insolvency. EMDEs do not have the fiscal and monetary capacity to respond as vigorously as their wealthier counterparts to counteract the damage that the pandemic and lockdowns is inflicting on their economies. While there are major cross-country differences within this group, EMDEs recovery is poised to be more protracted, feeding into the balance sheet frailties.

High leverage on the eve of the pandemic will act to amplify the balance sheet problems of the financial sector in many countries. The IMF has repeatedly flagged concerns about the pre-COVID rise in corporate leverage in many emerging markets, where much of the debt is denominated in US dollars. The two largest economies, the US and China, have highly leveraged corporate sectors Australia, Canada, and Thailand, among others have high or record levels of household debt. In Africa, where the non-performing loan (NPL) ratio was estimated at around $11 \%$ in 2019 , microfinance financial institution portfolios will come under stress as much of their lending is to households with volatile income and no assets.

Since the onset of the pandemic, a broad range of policies have been introduced by governments across the globe to provide liquidity to the many businesses that

\footnotetext{
3 The World Bank (2020a) documents the rise in global poverty rates during the pandemic; it is the first increase in this measure of poverty since the late 1990s.

${ }^{4}$ Cross-country studies that discuss or examine the antecedents of financial crises include: Conant (1909), Kindelberger (1978), Bernanke and James (1991), Caprio and Klingbiel (1996), Kaminsky and Reinhart (1999), Bordo et al. (2001), Reinhart and Rogoff (2009), Schularick and Taylor (2012), Laeven and Valencia (2013), Bordo and Meissner (2016).
} 


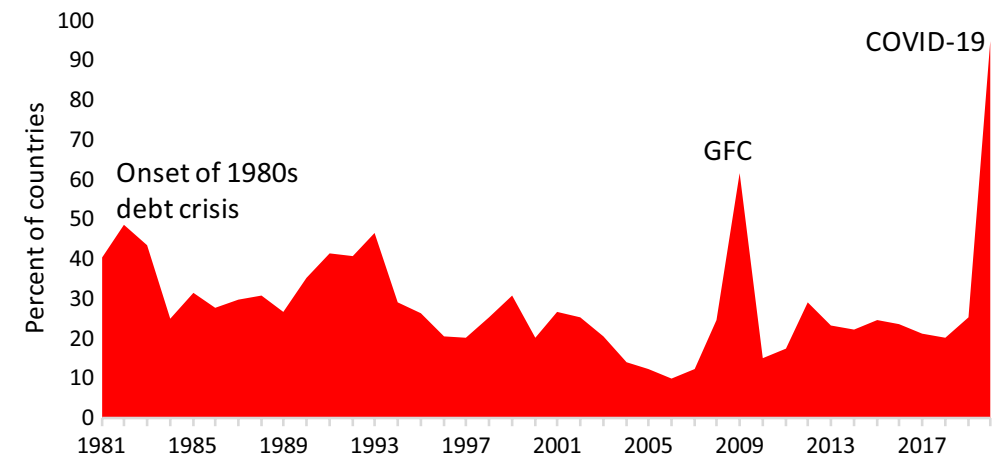

Fig. 1 Share of countries posting a decline in real per capita GDP: 1981-2020 (annual, in \%). Sources: International Monetary Fund, World Economic Outlook, October 2020, and authors' calculations

have been shuttered during the lockdowns and to support households hit by a sudden loss of income and employment. ${ }^{5}$ Grace periods in the repayment of existing loans have been granted. Re-contracting of loans in favor of longer maturities or lower interest rates have also been common. The hope is that because the health crisis is temporary, so too will be the financial distress of firms and households. However, even with a prompt resolution of the pandemic in the form of a globally available vaccine so that we acquire effective herd immunity, significant damage has been inflicted to the global economy and the balance sheets of financial institutions. Given the emergency, these policies have provided a valuable stimulus tool beyond the conventional scope of fiscal and monetary policy. But as grace periods come to an end, more will be revealed on whether the problem facing countless firms and households is insolvency rather than illiquidity.

The challenge for many EMDEs extends beyond household and corporate balance sheets and encompasses the sovereign. Today, more than half of low-income countries eligible for relief under the Debt Service Suspension Initiative (DSSI) are either in debt distress or at high risk. ${ }^{6}$ Several emerging markets have either recently restructured (Argentina and Ecuador) or remain in default (Lebanon, Surinam, and Venezuela). The recent evolution of sovereign credit ratings is informative; while $15 \%$ of the advanced economies have had their rating cut since the start of 2020, the comparable share of downgrades for EMDEs that are rated is almost $40 \%{ }^{7}$

The US Federal Reserve's dramatic interest-rate cut and other liquidity-enhancing measures in response to the pandemic have significantly eased global financial conditions for EMDEs and has kept the incidence on new sovereign defaults from

\footnotetext{
5 See World Bank (2020b) for a cross-country database on these policies.

6 World Bank (2020c). The country risk ratings and other details are available at https://www.worldbank. org/en/topic/debt/brief/covid-19-debt-service-suspension-initiative.

7 Based on Fitch, Moody's and Standard and Poor's sovereign ratings.
} 
spiking. ${ }^{8}$ This stands as a stark contrast to the historic interest rate hikes that ushered in the developing-country debt crisis of the 1980s. Nonetheless, many EMDEs have recorded significant capital outflows and markedly weakening currencies (in some cases outright currency crashes) during 2020. Furthermore, even before COVID-19, some large emerging markets (Argentina, Nigeria, and Turkey) as well as several of the low-income countries in debt distress have found it difficult to contain inflation to single digits.

The preceding narrative about current global fragilities places in context the topic I wish to address: Economic and financial crises in their various "guises or varieties." Historically, different types of crises (banking, sovereign external debt, currency, etc.) have often traveled together. These "conglomerate crises" re-enforce fault lines and dig the economy into a deeper hole, often complicating and delaying recovery. ${ }^{9}$

Charles Kindleberger observed in his classic book that "financial crises are hardy perennials." While crises are not exactly seasonal, their recurrence may be compared to that the Lochness Monster, who has presumably been around for several centuries. Just when the public forgets about Nessie, someone claims they just saw her raise her head. After a little more than a decade since the last bout of crises, concerns about evolving or impending crises are once again on the rise.

\section{Conglomerate Crises and Other Concepts}

This section opens by providing a sketch of individual crises "types" (banking, sovereign external debt, currency crash, etc.). Related concepts, such as differences between "default spells" and debt restructuring deals are discussed next. Lastly, I highlight the intersection of multifaceted problems, the conglomerate crisis, and its historical prevalence and connection to economic performance.

The definitions, concepts, and measurement used to date crises and related commentary and references are presented in Table 1. As the table highlights, the dating of crises involves both an "event" approach that relies on chronologies, announcements, and news and a "quantitative" methodology that focuses on the performance one or more economic and financial indicators relative to some threshold. The references provided in the table only scratch the surface of the voluminous existing literature. At any rate, the evidence linking the crises listed in Table 1 and economic performance (discussed in Sect. 4), suggests that the speed and shape of the postCOVID-19 recovery will depend importantly on how successful countries are in avoiding any or all these kinds of crises.

\footnotetext{
8 See Farah-Yacoub et al. (2021, forthcoming) for an encompassing database on sovereign defaults over 1800-2020.

9 See Kaminsky and Reinhart (1999) on banking and currency crises, Reinhart and Rogoff (2011a) on banking and external sovereign debt crises, and Reinhart (2018) on the "conglomerate" crisis.
} 


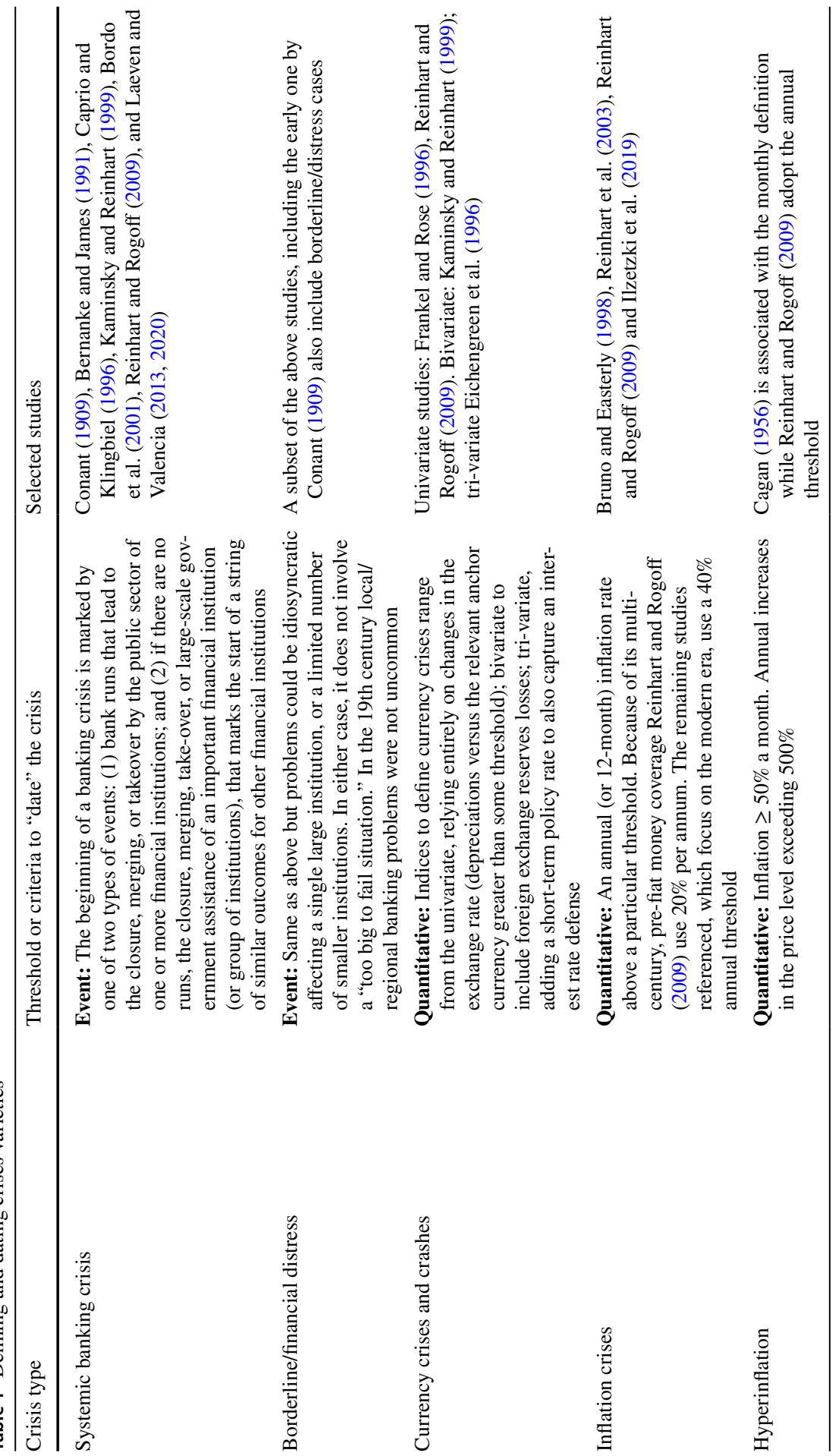




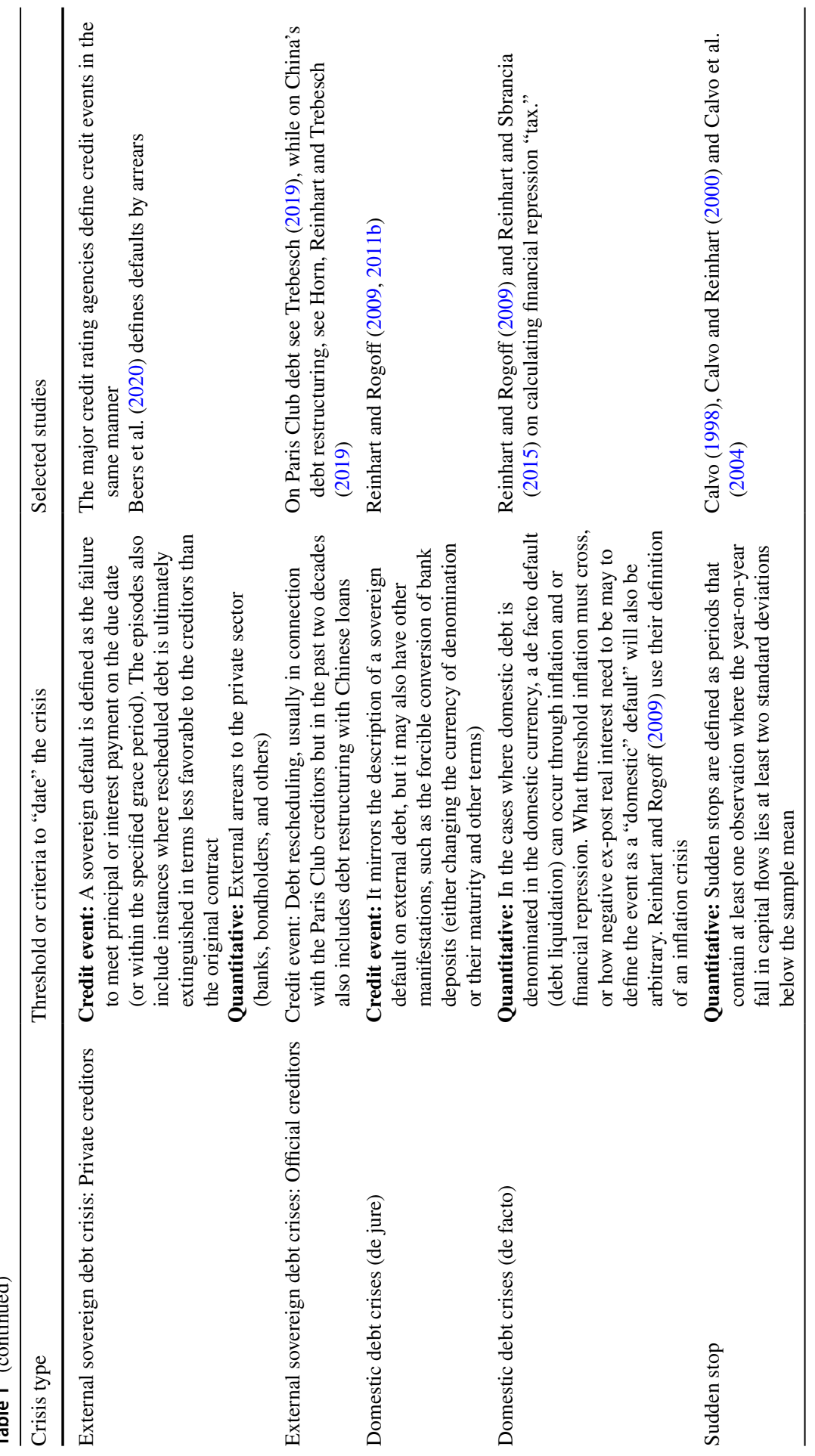

我造 


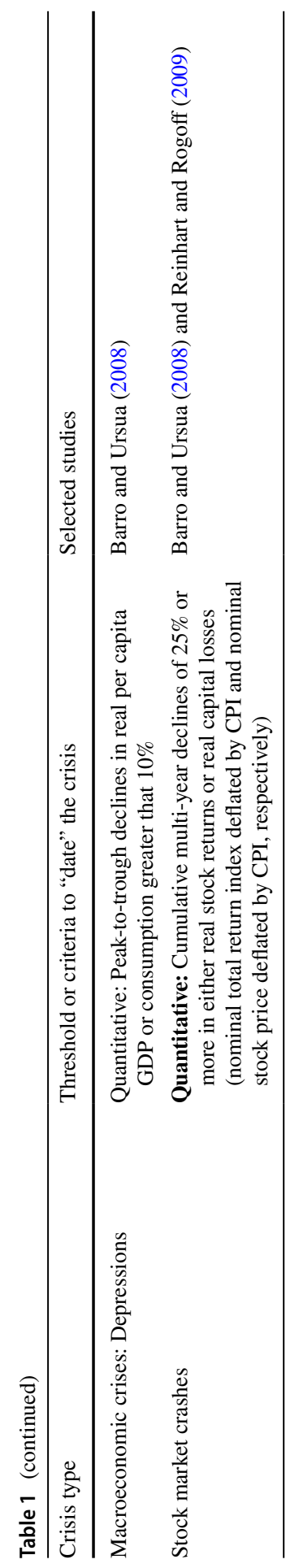




\subsection{A Note on Banking Crises in Market and Financially Repressed Economies}

Most of the literature on financial/banking crises has focused on episodes in partially-to-mostly liberalized market economies; these crises usually fit the "boombust" pattern described previously. In effect, some studies directly address the channels through which domestic financial liberalization may increase the odds of a banking crisis. ${ }^{10}$ For instance, financial liberalization can fuel credit booms in the commercial and shadow banking sectors through the removal of interest rate ceilings, lowering (eliminating) reserve requirements, allowing easier entry to the industry, permitting the introduction of new products or repackaging old ones, etc. Furthermore, if domestic liberalization is coupled with capital account liberalization, then integration into global capital markets also permit countries to "import liquidity" by borrowing from abroad (capital inflows). ${ }^{11}$

Studies of banking crises in financially repressed economies are comparatively rare. These episodes usually have different drivers and antecedents. A common cause involves lending to an inefficient and/or bankrupt public sector entity (controlled interest rates also figure prominently). ${ }^{12}$ Publicly owned banks may be particularly vulnerable to unprofitable directed credit. Also, for private banks holding a high proportion of their assets in government bonds or loans, a government default is devastating and part of the, so-called doom loop. Even in the absence of an outright sovereign default in its external debt, a government build-up of late payments (arrears) to its domestic bank creditors directly or to its suppliers (who, in turn, may run up arrears on their loans) places financial institutions at risk. ${ }^{13}$

Domestic debt has provided much, if not most, of the COVID-19 deficit financing for governments. This observation is applicable across regions and income groups. Much of the newly issued domestic government debt has been bought by central banks, as these have attempted to ease liquidity, but a great deal of this debt is now the hands of banks. In light of the weakening balance sheets of many banks and sovereigns, the potential for doom-loop risks has increased as a consequence of the pandemic.

\subsection{Sovereign Default Spells and Interim Serial Restructuring}

As discussed in Graf et al.(2021), while serial default, a term coined by Reinhart et al. (2003), refers to countries with a track record of more than two default spells or episodes, interim serial restructuring refers to restructuring within a default spell that do not bring the debt crisis to closure. The longer duration of the default spells of the 1930s and the 1980s were particularly prone to serial restructuring. These data underestimate the number of debts restructuring deals in many episodes. This

\footnotetext{
${ }^{10}$ See Diaz-Alejandro (1985), Kaminsky and Reinhart (1999) and Reinhart and Rogoff (2009).

${ }^{11}$ See also McKinnon and Pill (1996).

12 See Calice et al. (2020).

${ }^{13}$ See Bosio et al. (2021).
}

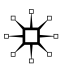


is because existing databases do not include restructurings that were intended to be temporary by design. The G20's DSSI in response to the pandemic is a very special example of a temporary measures. ${ }^{14}$ On average, it took two restructurings before a sovereign's default was settled "sustainably."

\subsection{Conglomerate Crises}

Severe crises seldom travel alone. ${ }^{15}$ In particular, sovereign debt crises, more so than banking crises, currency, or stock market crashes, are often of the "conglomerate" variety and are usually associated with economic depressions. ${ }^{16}$ A conglomerate crisis usually involves three or more of the types of crises described in Table 1, although the composition usually varies by episode.

Reinhart and Rogoff (2014), for instance, centered their analysis on the 100 worst financial/banking crises over 1857-2013. "Worst" was defined by the severity of the recession/ depression that accompanied the banking crisis. ${ }^{17}$ The 25 most severe episodes (the worst of the worst) are listed in a colorful Table 2, starting with the most severe. The color-coding (see legend) corresponds to the types of crises that emerged during the episode. Table 2 excludes two other frequent companions to these crises: stock market crashes and inflation crises. The magnitude of the output losses and the duration to recovery will be discussed in the next section. ${ }^{18}$

Argentina's famous 2001 episode (22nd place in Table 2 and shown in orange) provides an example of a particularly encompassing conglomerate crisis. The episode involved a banking crisis (with an almost continuous drain of bank deposits through 2001), a spectacular currency crash, as the one-to-one convertible peso was abandoned, a default on external debt, and a default on domestic debt (also as US dollar deposits in the banking system were forcibly converted to pesos). Inflation rose markedly, the equity market sank, and the peak-to-trough decline in real per capita GDP amounted to almost 21\%, meeting the Barro and Ursua (2008) definition of a depression. Among the "core crises" the tally was four (banking, currency, external sovereign debt, and domestic debt); An expanded tally would score a seven (adding inflation, stock market crash, and economic depression.)

A major takeaway from Table 2 is that only five of the "worst of the worst" 25 banking crises episodes were "pure" banking crises, in that these episodes did not involve a currency crash or a sovereign debt crisis of either the external or domestic variety. If stock market crashes are also included as a separate crisis category in this exercise, the "pure" banking crises category would almost shrink to the null set. ${ }^{19}$

\footnotetext{
${ }^{14}$ For a discussion of some of these temporary deals see Cruces and Trebesch (2013).

15 See, for instance, Bernhard et al. (2006) on debt, currency and banking.

16 See Barro and Ursua (2008), Reinhart (2018) and Table 1 for individual crises definitions.

17 Our preferred measure of severity is described in Sect. 4.

18 See Reinhart and Rogoff (2009), on a "composite crisis index" with and without equity market crashes.

19 See Kaminsky and Reinhart (1999), Reinhart and Rogoff (2009) and Barron et al. (2021).
} 
Over the full 100 crisis sample more than half (56 episodes) of the banking crises were accompanied by a currency crash within a two-year window; post 1900, the share of "twin crises" (banking and currency crisis) rises to about $70 \%$.

A quarter of the banking crises also involved a sovereign credit event (outright default or debt restructuring). Another nine involved large-scale bailouts from the IMF and international community to avoid a sovereign credit event. Combined, over a third (34) of the banking crisis episodes also involved a sovereign debt crisis. Practically all the simultaneous debt and banking crises episodes but the Greek 2008- crisis were "triplets". Banking and sovereign debt crises without a currency crash are quite rare, with fully dollarized Panama in the late 1980s providing another example beyond Greece, which remained in the euro area.

In the search for solutions, policy makers must be cognizant that they may be facing multifaceted and interconnected problems. In the context of an external sovereign debt crisis, debt restructuring may be critical. But it won't solve a chronic inflation problem, for example. A rescue of the banks, even a well-designed one, may leave the sovereign in a vulnerable fiscal position or undermine the currency. Even leaving out structural economic problems, such as low productivity or high poverty rates, a conglomerate crisis requires a broad toolkit and an integrated approach.

\begin{tabular}{ll} 
Within a two-year window of the banking crisis \\
\hline Coding & Types of crises \\
& Banking, currency, and sovereign debt \\
& Banking and currency ("pure” twin crisis) \\
Banking and sovereign debt (relatively rare) \\
Banking only
\end{tabular}

Source: Reinhart (2018)

\section{Recessions, Depressions, and Recovery}

The preceding narrative suggests that: (1) The incidence of sovereign debt/fiscal problems is on the rise; (2) Debt crises are often accompanied by currency, banking, and inflation crises of varying severity. (3) Sudden stops are another risk. Thus, many countries may be facing the risk of a conglomerate crisis at time when they are attempting to recover from the ravages of COVID-19. These observations lead to the related question of how deep will output losses be and how long might it take countries to recover.

To address this question, I first review past recoveries from a variety of crises (including conglomerate cases), along the lines of Reinhart and Rogoff $(2009,2014)$ and Reinhart (2018). Secondly, I focus on recoveries from the 1980s crises wave in EMDEs and how that experience compares to the prevailing outlook (based on the October 2020 WEO) for the post-COVID-19 recovery. Outcomes of and the outlook for inflation are briefly discussed. 
Table 2 The "Worst of the Worst" Financial Crises. Sources: Reinhart and Rogoff (2014) and Reinhart (2018)

\begin{tabular}{|c|c|c|c|c|c|c|}
\hline & Years & Country & $\%$ change peak & Number of year & & Severity index \\
\hline & & & & Peak to trough & $\begin{array}{l}\text { Peak to } \\
\text { recovery }\end{array}$ & \\
\hline 1 & 1926 & Chile & -46.6 & 3 & 16 & 62.6 \\
\hline 2 & 1931 & Spain & -34.6 & 9 & 26 & 60.6 \\
\hline 3 & 1983 & Peru & -32.0 & 11 & 25 & 57.0 \\
\hline 4 & 1931 & Uruguay & -36.1 & 3 & 17 & 53.1 \\
\hline 5 & 1893 & Australia & -28.0 & 8 & 20 & 48.0 \\
\hline 6 & 1929 & Mexico & -31.1 & 6 & 16 & 47.1 \\
\hline 7 & 1921 & Italy & -25.5 & 3 & 21 & 46.5 \\
\hline 8 & 1890 & Brazil & -21.7 & 4 & 21 & 42.7 \\
\hline 9 & 2008 & Greece & 26.3 & 6 & 16 & 42.3 \\
\hline 10 & 1890 & Uruguay & -21.0 & 2 & 19 & 40.0 \\
\hline 11 & 1981 & Philippines & -18.8 & 3 & 21 & 39.8 \\
\hline 12 & $1980 / 1985$ & Argentina & -21.8 & 11 & 18 & 39.8 \\
\hline 13 & 1929 & India & -8.2 & 9 & 31 & 39.2 \\
\hline 14 & $1929 / 1933$ & US & -28.6 & 4 & 10 & 38.6 \\
\hline 15 & 1994 & Venezuela & -24.2 & 11 & 14 & 38.2 \\
\hline 16 & 1939 & Netherlands & -16.0 & 6 & 21 & 37.0 \\
\hline 17 & $1931 / 1934$ & Argentina & -19.4 & 3 & 15 & 34.4 \\
\hline 18 & 1931 & Poland & -24.9 & 4 & 9 & 33.9 \\
\hline 19 & $1929 / 1931$ & Austria & -23.4 & 4 & 10 & 33.4 \\
\hline 20 & 1981 & Mexico & -14.1 & 7 & 17 & 31.1 \\
\hline 21 & 1920 & UK & -18.7 & 3 & 11 & 29.7 \\
\hline 22 & 2001 & Argentina & -20.9 & 4 & 8 & 28.9 \\
\hline 23 & 2008 & Italy & -11.9 & 6 & 16 & 27.9 \\
\hline 24 & 1980 & Chile & -18.9 & 2 & 8 & 26.9 \\
\hline 25 & 2002 & Uruguay & -18.9 & 4 & 8 & 26.9 \\
\hline
\end{tabular}

Crisis Severity: Percent in Per Capita GDP, Duration of Contraction and Years to Full Recovery in 25 of the Worst Systemic Banking Crises, 1857-2018

\subsection{0 crises}

The point of departure is a minimalist definition of economic recovery that focuses on how long it takes real per capita GDP to get back to its pre-crisis level. It is silent on possible effects of the crisis on potential output. The measure of the depth of the 
recession is standard and focuses on the peak-to-trough decline in real per capita GDP. ${ }^{20}$ We also tally the number of years it takes to reach bottom in each episode. While the view that recessions associated with financial crises are deeper has gained ground in recent years, academic opinion is more divided on how to characterize recoveries from crises. ${ }^{21}$

The duration measure is the number of years it takes to reach the prior peak in real per capita income. Fatás and Mihov (2013) and others note that this definition does not capture a return to potential output or to some predetermined trend. Of course, normalizing by population does allow for some time variation in underlying trend output. In contrast to NBER dating of turning points, our approach treats any renewed downturn that takes place before the economy reaches the prior peak as a "double dip" and part of the same cycle (our dating is based on the global peak to date). The severity index, shown in the last column of Table 2, is given by,

$$
\begin{aligned}
\text { Severity index }_{\mathrm{i}}= & - \text { Peak-to-trough } \% \text { change }_{\mathrm{i}} \\
& + \text { Number of years from peak to recovery of prior peak }{ }_{\mathrm{i}} .
\end{aligned}
$$

There are numerous other ways of gauging the severity of a crisis as it relates to output (including focusing on shortfalls relative to potential output). The simple measure described lends itself to comparisons across time and space (specifically to eras or countries where population growth is/was significantly greater than what we observe today, particularly in the advanced economies).

A key takeaway from Table 2 is that, apart from sharp output declines," the worst of the worst" financial and conglomerate crises left a long-lasting imprint on economic well-being. As the table highlights, it often takes per capita GDP more than a decade (three decades is the record) to recover. Of course, in several of these episodes, economics is only a part of the story, as coexisting wars or civil unrest take their own toll on economic activity. For the full sample of 100 crises, Reinhart and Rogoff (2014) report that the average and median number of years to full recovery is 8 and 6.5 , respectively.

\subsection{Post-COVID-19 Expected Recovery in Historical Context}

The preceding evidence encompassed almost two centuries and included advanced and developing economies. I now focus more narrowly on the last wave of debt and financial crises in EMDEs during the 1980s. ${ }^{22}$ Mexico's famous default in August 1982 set off a domino effect in already extremely vulnerable developing economies. However, several smaller countries (Costa Rica, Honduras, Liberia, Sudan, Tanzania, Uganda, among others) were already in default in 1981. So, for comparison

\footnotetext{
${ }^{20}$ See Barro and Ursua (2008) for a related discussion of the measurement of output collapses.

21 For a discussion of these and other issues relating to the measurement of economic cycles, see for instance, Fátas and Mihov (2013), whose analysis is informed by both the modern literature and the early work pioneered at the National Bureau of Economic Research (NBER).

22 The discussion that follows is based on the October 2020 World Economic Outlook database and projections.
} 
purposes to the COVID-19 shock, I benchmark 1980 as the pre-crisis equivalent to 2019 (ie, $1980=2019=100) .^{23}$

In 1986, 55\% of the EMDEs recorded real per capita GDP levels that were below those in 1980. By 1990 the situation had not improved, as 58\% of EMDEs had real per capita GDP below the 1980 benchmark. ${ }^{24}$ The lost decade adage applied to the majority of emerging and developing economies, many of which were coping with conglomerate crises. During this period, reality consistently disappointed expectations, successive downward revisions to economic growth projections were legion.

The experience of the 1980s suggests caution is warranted in projections of postCOVID economic growth, particularly for countries that are already experiencing some variants of financial stress. The October 2020 WEO projections show that by 2025, 29\% of EMDEs have per capita incomes below what they were in 2019 (the comparable share for EMDEs is $94 \%$ in 2020). This is only slightly higher than the share in any "normal" year and spectacularly better than the track record of the 1980s. It is difficult to reconcile this GDP path with the prevalent expectation that there will be a higher incidence of sovereign debt and financial sector problems in the period ahead.

Inflation in some EMDEs may also surprise on the upside. At present, the substantial contraction in aggregate demand acts to dampen inflationary pressures. However, a frequent component of the composite crises that I have described involves inflation, a point stressed in Reinhart and Rogoff (2009). A country losing access to external capital markets, relies more on domestic funding sources to meet the government's financing needs. For many developing countries, the scope for internal financing is limited and governments turns more to the revenue for money creation and, in many cases, government arrears.

I am not suggesting a full-blown reversion to the 1980s, when more than half of the EMDEs had double-digit inflation (Fig. 2) and inflation targeting was still limited to a handful of advanced economies. The share of countries with double-digit inflation rates has dropped precipitously since then, possibly hitting a low point in 2014 (7\% of EMDEs registered double-digit inflation that year). In 2020 that share is about $14 \%$. But not surprisingly, the re-appearance of double-digit inflation is clustered in countries that are also experiencing currency crashes and in some cases are already in debt distress.

Currency crashes, on which I have been comparatively silent, are an integral part of inflation dynamics, as the Global Financial Crisis short-lived spike highlights in Fig. 3. The larger concern is whether currency weakness in a growing number of EMDEs becomes a more persistent feature of the post-COVID landscape that feeds into both inflation and foreign currency debt servicing difficulties for both governments and corporates.

\footnotetext{
23 As already noted, even before COVID-19 the were a number of countries in crisis.

${ }^{24}$ In any given random year, anywhere between 16 and $21 \%$ of the countries will have a lower per capita income tan five years prior. So the 1986/1981 comparison at 55\% is more than double the "normal" rate.
} 


\section{The Stages of Debt and Financial Crises and Their Resolution}

Turning to the resolution of banking and sovereign debt crises, Laeven and Valencia (2013) have documented that banking crises often take 3-4 years to resolve. ${ }^{25}$ Sovereign external debt crises (default spells) take longer, with a post-WWII mean and median of 5 and 7.9 years, respectively. While each episode has its own dynamics, a key observation is that the road to resolution is marked by different stages of progress (or lack thereof). Table 3 groups these stages into 6 buckets for succinctness.

\subsection{Denial}

At the outset of banking and sovereign debt problems it is often asserted that the problem is liquidity, not solvency. Sometimes, of course, it is a liquidity problem. Ex-ante it is often difficult to diagnose whether the adverse shock triggering the alarm is temporary or permanent (or more accurately, very persistent). Overoptimism on the "temporariness" of the shock can lead to inaction on the policy front. Opaque balance sheets (sovereign, central bank, corporates, banks or any combination of these) can also contribute to the misdiagnosing the problem. Hidden debts, in their countless guises, are usually still "hidden" at this stage. Box 1 illustrates, with examples from past crises the complexity and time variation in the hidden debt problem.

As noted earlier, a variant of the hidden debt problem for financial institutions (banks and shadow banks) in the context of the COVID-19 crisis is the possible underreporting of non-performing loans in an environment when repayment has been suspended temporarily. But as grace periods come to an end, more will be revealed on whether the problem facing countless firms and households is insolvency rather than illiquidity.

On the sovereign debt side, the hidden debts problem is complex as explored in Box 1. During the period of relative prosperity that lasted until around 2014, many low-income countries accumulated significant debts to China and to other non-Paris Club creditors that are relatively new in this marketplace. ${ }^{26} \mathrm{~A}$ substantial share of these debts went unrecorded in major databases and was not on the radar screen of credit rating agencies. External borrowing by state-owned (or guaranteed) enterprises, which have much more uneven reporting standards also escalated. Public domestic debt (which was a minor issue in the 1980s debt crisis in developing countries) is much larger now and data availability lags its external counterpart (particularly on ownership).

\subsection{Gambling for Resurrection}

Is well known in the literature on banking and denotes excessive risk-taking by troubled banks. The management is aware of the solvency problem and may

25 Encouragingly, they also document that a significant share of episodes were resolved in a year.

26 See Horn et al. (2019). 


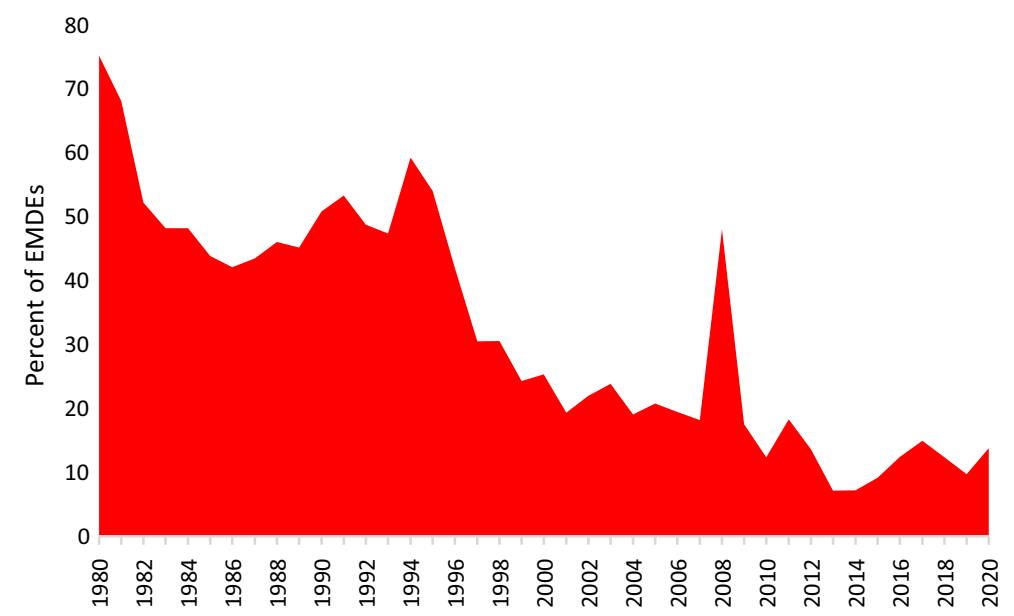

Fig. 2 Share of EMDEs with double-digit inflation rates: 1980-2020 (in \%). Sources: World Economic Outlook, October 2020 and author's calculations. Notes: Annual average consumer price inflation.

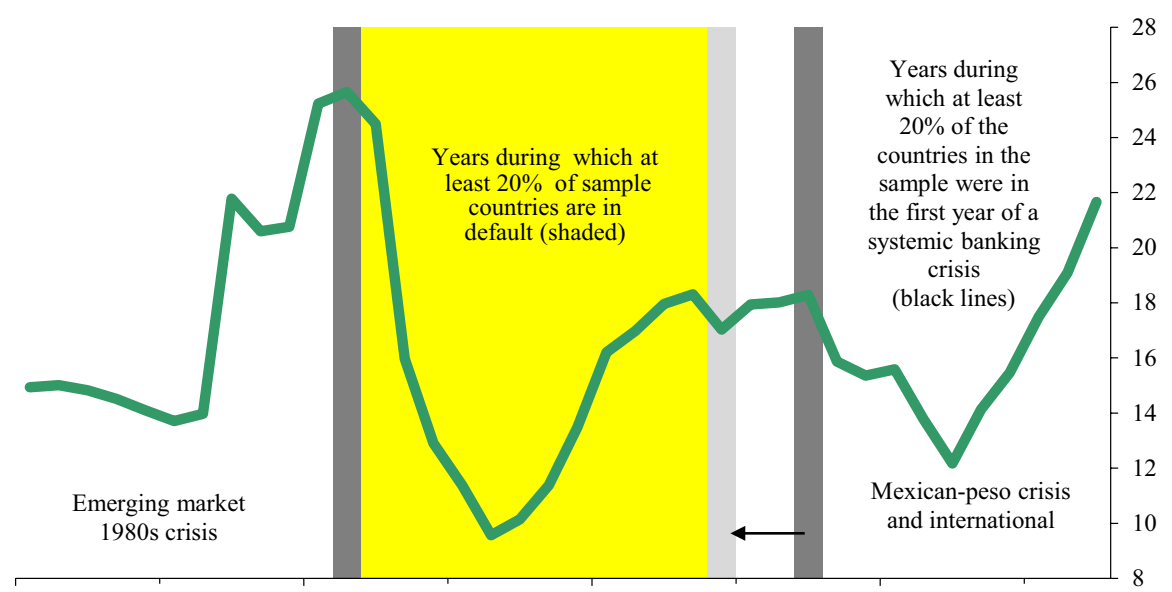

1970197219741976197819801982198419861988199019921994199619982000200220042006

Fig. 3 Share of Short-term Gross External Debt (Public plus Private): Emerging Markets, 1970-2009 (in $\%)$. Source: Reinhart and Rogoff (2011a)

borrow (usually short-term and at high rates) to pay off depositors (Velasco 1987 stresses moral hazard), offer ever higher deposit rates to attract depositors (RojasSuarez 2002), and lend short-term risky projects in the hope that the "gamble" will pay off. It is difficult to document when these strategies have paid off and a crisis avoided for individual banks. At the aggregate sectoral level, many of the banking crises in the 100 discussed previously were preceded by surges in bank's offshore borrowing at shorter maturities. This is captured in Fig. 3 for the aggregate EMDEs, which shows the share of short-term gross external debt (public 
Table 3 Stages in a sovereign debt or banking crisis gleaned from the historical experience

1. Denial: At the outset of a crisis, it is often asserted that the core problem is liquidity rather than solvency (of course, sometimes it is a liquidity problem). Opaque balance sheets often complicate the diagnosis for both financial institutions (banking crisis) or the government (sovereign debt crisis)

Banking crises. NPLs, existing maturity and currency mismatches may be underestimated, for instance

Sovereign debt. The opaqueness in the sovereign balance sheet, may arise from a variety of hidden debt problems arising from existing debt obligations, contingent liabilities, or both (see Box 1)

2. Gambling for resurrection: A solvency problem is strongly suspected or may even be known but not publicly acknowledged. But there is a hope of a miraculous economic recovery or large-scale bailout. The problem continues to be diagnosed as a liquidity problem. Illiquidity may be addressed by fresh lending/borrowing. It is during this period, that the maturity composition of debt often changes markedly, with a skewing to short-term debt

Banking crises: At the private level, this stage can go on for extended period (as banks evergreen problem assets). This practice usually prolongs the credit crunches that often follow banking sector problems, as "fresh: lending is residual

Sovereign debt: In the early stages of the 1980s crisis, bridge loans (Cruces and Trebesch, 2013, Appendix on excluded cases) were commonplace. As Fig. 3 highlights, average maturities on outstanding external debt declined. Broner et al. (2013) present evidence of the sharp steepening of the yield curve prior to EM crises. Roll-over risks are often overlooked or underestimated. IMF and multilateral lenders enter (or re-enter) the scene, as financing gaps widen

3. The morning after gambling: The solvency problem of the financial institution(s) or sovereign is openly acknowledged

Banking crises: Governments will begin the process of bailing out institutions, merging others, setting up bad banks, etc. If the extent of the problems is not yet fully known initial actions may fall short of what is needed. (Note: Skip to stage 6)

Sovereign debt: There is the admission that debt restructuring is needed. The eternal divide between debtors, who want haircuts and the creditors, who want repayment ensues

4. Early shallow restructurings (sovereign debt): These early attempts to restructure are often characterized (some cash flow relief). For debtors, these restructurings a short-lived reprieve; for creditors time to (gradually) adjust their exposure and leverage to the distressed debtors. Overoptimistic economic projections also contribute to the observed undershooting in the magnitudes of debt relief

Delay also helps both sides bargain for larger infusions from official creditors (Bulow and Rogoff 1989). See also Graf Von Luckner et al. (2021) for a summary of the recent literature onther factors driving delays in debt crisis resolution

5. That did not work, let's repeat a variant of 4-maybe it will work this time: (sovereign debt): This process can be repeated several times, as documented in Cruces and Trebesch (2013), Meyer et al. (2022). Within a single sovereign default spell, there have been as many as eight serial restructuring deals; the median is 2 (see Graf Von Luckner et al. 2021)

6. Bite the bullet--resolution: Measures commensurate with the scale of the problem are adopted, restoring sufficient balance sheet health for financial institutions (banking crisis) or governments (sovereign debt)

Banking crises: While there are cases where a comprehensive clean-up of financial sector balance sheets is spread out over many years (Japan's crisis in the early 1990s is an example), banking crisis resolution is speedier than its sovereign debt crisis counterpart

Sovereign debt: Through the process of elimination and the passage of time creditors arrive at the conclusion that significant debt reduction is necessary to "cure" the debt problem and restore sustainability. Debtors had usually reached that conclusion years earlier. The average duration of default spells over 1946-2020 is 7-8 years. As noted, many of these default spells involve multiple intermediate debt restructuring deals (see Graf Von Luckner et al. 2021)

plus private) on the eve of banking and sovereign external debt crises. More granular country specific data is presented in Reinhart (2010). 
Box 1 Hidden debts: Unpleasant surprises that when revealed have undermined the credibility of existing safety nets and may set runs in motion

Central bank debt: To this day, even when the numbers are published, these are not included as part of general government debt (ie, Argentina's short-term Lebacs). In the event of Euro-area exits, Target2 balances (currently running at around 20-40\% of GDP for Greece, Italy, Portugal and Spain) are external central bank debt. Unseen: In June 1997, the new Thai finance minister 'discovered' that the Bank of Thailand had already spent US\$ 28 billion out of US\$ 30 billion of its international reserves in the course of forward market interventions to defend the baht

Non-securitized, floating debt (arrears): Unpaid bills to suppliers and, in more desperate cases (Russia 1998) unpaid pensions and wages to public sector employees

Misreporting and other off-balance sheet: Greece-Goldman Sachs debt swaps: Greek dollar and yendenominated debt was swapped at historical euro exchange rates to cosmetically reduce the overall level of debt

Debts to China; Even the most comprehensive databases on external debt, such as the World Bank's Debt Reporting System, did not fully capture liabilities of governments and SOEs in numerous lowincome countries, over much of the $2000 \mathrm{~s}$

Offshore derivative operations of banks: These can leverage banks' holdings of government debt (a significant hidden debt problem during the Mexican banking/peso crisis of 1994-1995). With Mexican bond (Tesobonos) as collateral, Mexican banks took on short-term dollar debt, that was for the most part unhedged. As the value of the collateral sank, margin calls increased along with rollover risk

Implicit guarantees and moral hazard: Private sector debt Especially external debt of banks (DiazAlejandro 1985) can overwhelm an otherwise healthy fiscal situation (Chile 1981, Iceland, Ireland, Spain, 2007-2008); corporate debt (Korea and Indonesia, 1997). Puerto Rico's "appropriation debt."

Puerto Rico (PR) began issuing "Appropriation bonds" in 2000 indirectly through government-owned entities and made repayment contingent upon the Legislature's appropriating funds for this purpose. These bonds are not counted as debt under the debt limit. Yet PR appropriation debt was, for practical purposes, guaranteed by the government and charged to its taxpayers

For sovereigns, gambling for resurrection has also involved taking on costlier and usually shorter-maturity debt (as in Fig. 3). Broner et al. (2013) present evidence of the sharp steepening of the yield curve prior to EM crises. Roll-over risks are often overlooked or underestimated. IMF and multilateral lenders may enter (or re-enter) the scene, as financing gaps widen. Cruces and Trebesch (2013, appendices) document the frequent reliance on "bridge loans" during the early stages of the 1980s EMDE debt crisis.

The shift toward short maturities provides the classic setup for a "run." The run can be on bank deposits or in other markets (Reinhart 2018). On deposits, it can be along the lines of Bryant (1980) or Diamond and Dybvig (1983) or other asset markets (see Chang and Velasco 2000; Allen and Gale 2007; Gorton 2010). On the creditor side, the private creditors often play that game by lending short and at very high yields. When repayment is not forthcoming, their answer is "we thought we could have return without risk". And for the multilaterals, the tendency is to try to help governments at that stage, often effectively lending into what is a non-sustainable debt. The third stage is the morning after the gambling, and the realization that restructuring is needed. The cast of characters has changed, but the problems today are very similar to the ones in the past, which is creditors do not want haircuts and debtors need debt relief. 


\subsection{In the Morning After Gambling}

The solvency problem of the financial institution(s) or sovereign is acknowledged. Banking crises: Emergency measures, such as bank holidays or some form of deposit freeze, capital controls, may be adopted. In some semi-dollarized economies foreign currency bank deposits were forcibly converted to local currency; maturity conversion of deposits (lengthening) of Governments will begin the process of bailing out institutions, merging others, setting up bad banks, etc. For a crisis-by-crisis sketch of some of the policy responses adopted, see Laeven and Valencia (2013). If the extent of the problems is not yet fully known initial actions may fall short of what is needed. (Note: Skip to stage 6)

\subsection{Sovereign Debt}

There is the admission that debt is unsustainable - that there is a solvency problem. The country may openly default or begin to seek a debt restructuring. In either case, this point marks the start of the default spell. The eternal divide between debtors, who want haircuts and the creditors, who want repayment ensues. Complicating matters, the awareness of hidden debt problems (as in Box 1) starts to emerge.

Default spells often include "debt with drama" and "debt without drama." The drama is usually reserved for the outset, as the crisis erupts. But debt crises have lingered without drama for years. ${ }^{27}$ Countries shut out of capital markets often face all kinds of derivative problems (lack of domestic credit, build-up of arrears, sluggish growth, reliance on inflationary finance, etc.,). Debt without drama may attract little attention if the country(ies) affected are not "systemic," in terms of impacting the working of global capital markets. Figure 4, from Graf von Luckner et al. (2021), presents the marginal and cumulative frequency distributions of the duration (in years) of 279 external default spells (excluding repudiation cases) in 113 countries over 1800-2020. The average default spell for the full sample lasted ten years, while the median is seven years. These descriptive statistics highlight the slow-moving nature of debt crisis resolution, an issue I will address in Sect. 4. A significant share of the longest multi-decade episodes involved wars or internal civil conflict and predate the 21 st century. As shown, since the end of World War II, default spells have become shorter, lasting on average 7.9 years, with a median duration of 5 years.

\subsection{Early Shallow Restructurings (Sovereign Debt)}

These early attempts to restructure are often characterized by the provision of some cash flow relief without necessarily reducing the intertemporal debt burden. For debtors, these restructurings provide a short-lived reprieve; for creditors, it provides time to adjust their exposure and leverage to the distressed debtors more gradually. Overoptimistic economic projections (see Ghosal and Miller 2017) also contribute

$\overline{27}$ See Reinhart and Rogoff (2009).

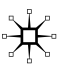


to the observed undershooting in the magnitudes of debt relief. Figure 5, from Reinhart and Trebesch (2016) illustrates the protracted multi-stage process of sovereign debt restructuring during the historical episodes (the interwar and the 1980s) where sovereign defaults and debt challenges escalated.

Delay also helps both sides bargain for larger infusions from official creditors (Bulow and Rogoff 1989). Graf Von Luckner et al. (2021) provide a summary of the recent literature onther factors driving delays in debt crisis resolution. Creditors' co-ordination problems that lead to holdouts and increased are among the factors they highlight. ${ }^{28}$ In addition, shifts in debtor bargaining power can lead to longer default spells, as can business cycle conditions in the creditor country (Benjamin and Wright 2009; Asonuma and Joo 2020). Trebesch (2019) focuses on political instability in the debtor country as a factor that can delay and derail and effective debt restructuring. This problem can be self-reinforcing, as economic crises often undermine the political situation, which in turn, increase uncertainty about the current government's ability to deliver the future reforms needed to restore solvency.

\subsection{That Restructuring Did Not Work, Let's Repeat a Variant of It-Maybe It Will Work This Time (Sovereign Debt)}

There are cases where creditors and debtors have come to very successful agreements relatively quickly, but the "typical" default spell involves, on average, two restructurings (the post 1920s median is also 2), as documented in Graf Von Luckner et al. (2021). ${ }^{29}$ Poland holds the record, as during its lengthy default spell (1981-1994) there were 8 debt restructurings (seven of these interim). Democratic Republic of Congo, Jamaica, and Nigeria follow closely with 7 restructurings each. Chad is seeking its third restructuring since 2014, highlighting serial restructurings are not a relic of the past.

Stage five, thus, looks a lot like stage four. The rationale offered, as to why a similar restructuring may work this time varies not only considerably across countries but also for the same country over the course of the default spell. This process can be repeated until (ultimately) the restructuring is successful in restoring debt sustainability in the "bite the bullet" stage. Serial restructurings often start with deals that offer some cash flow relief and have often (but not always ended with face value reductions).

\subsection{Bite the Bullet}

For banking crises, this stage is when bank balance sheet health is restored by the write-off or sale of non-performing assets. The end or major reduction in "evergreening" allows new lending to resume. Indeed, in dating the "end" of a banking

\footnotetext{
28 See Pitchford and Wright (2012), Fang et al. (2021), Schumacher et al. (2021).

29 For examples of one-time successful restructurings, see Cruces and Trebesch (2013) and the update in Asonuma and Trebesch (2016).
} 
Marginal frequency distribution

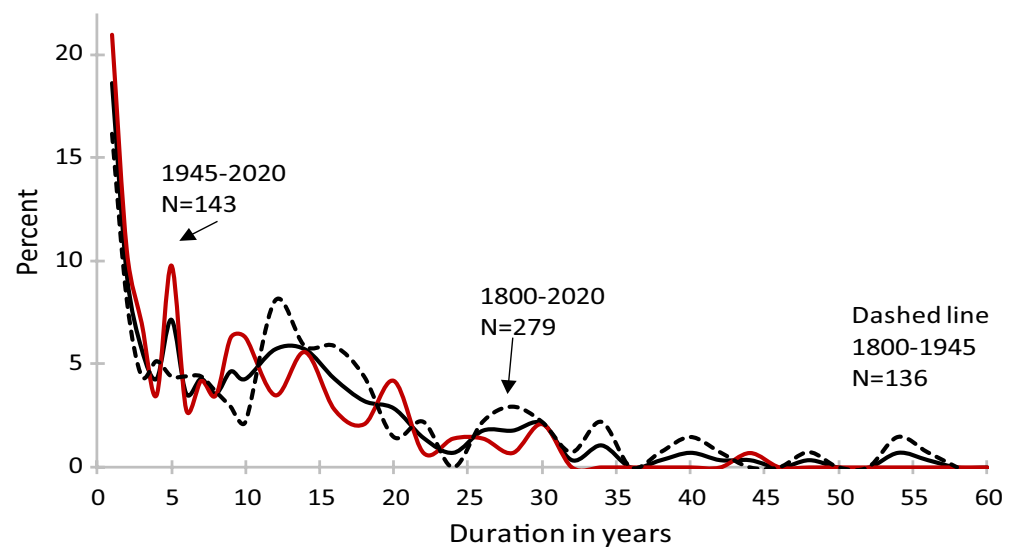

Cumulative frequency distribution

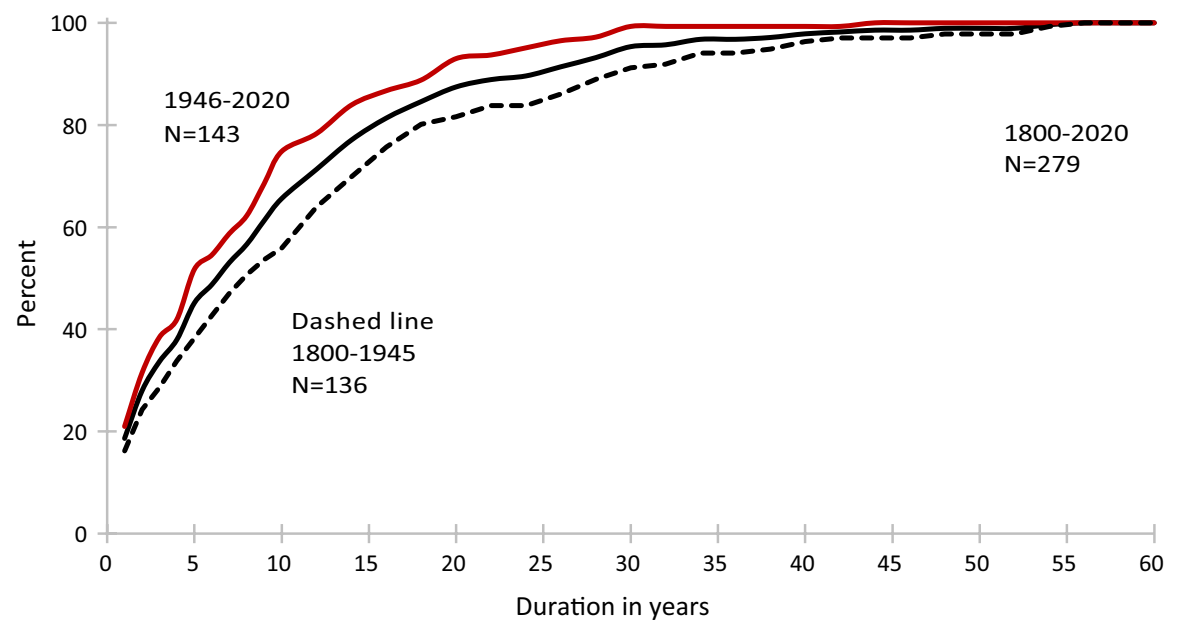

Fig. 4 The duration of defaults: 1800-2020. Source: Farah-Yacoub, Graf von Luckner, and Reinhart (2021)

crisis for cases where a decisive event (a transfer of bank of non-performing loans to a "bad bank", for instance), Laeven and Valencia (2013) mark the end through the resumption of credit growth.

Sovereign debt crises are "cured" when debt sustainability and renewed capital market access is restored (the extent of access varying substantially across countries). At the bite-the-bullet stage, it is widely recognized that wealth has been lost, and that the probability of substantial repayment is nil. Creditors usually reach that point after alternatives failed. The Brady Plan in the early 1990s, for mostly middle-income economies, and the HIPC Program that was launched 
$1920 \mathrm{~s} / 1930 \mathrm{~s}$

\begin{tabular}{|c|c|c|c|}
\hline$T$ & $T$ & $T$ & $T$ \\
\hline $\begin{array}{l}\text { First defaults } \\
\text { early-1920s }\end{array}$ & $\begin{array}{l}\text { Debt Reschedulings } \\
\text { of the mid-1920s }\end{array}$ & $\begin{array}{l}1931 \text { Hoover } \\
\text { Moratorium }\end{array}$ & $\begin{array}{l}1934 \text { Default } \\
\text { and Write Off }\end{array}$ \\
\hline & cash flow relief & $\rightarrow$ cash flow relief & $\rightarrow$ debt stock reduction \\
\hline
\end{tabular}

1980s/1990s

\begin{tabular}{r|r|r|r|}
\hline $\mid$ & $\mid$ & $\mid$ & $\mid$ \\
Defaults, Rollovers and & Baker Plan & Brady Plan \\
Reschedulings after 1982 & $(1986)$ & $(1990)$ \\
$\rightarrow$ cash flow relief & $\rightarrow$ cash flow relief & $\rightarrow$ debt stock reduction
\end{tabular}

Fig. 5 Stylized crisis timeline of the 1920s/1930s and 1980s/1990s Source: Reinhart and Trebesch (2014)

in 1996 for the low-income countries brought closure to many countries whose debt crises started in the early 1980s. As Meyer et al. (2019) document, almost all defaults of the past 200 years have been solved by a debt exchange of old into new debt at a discount-with an average haircut to creditors of $44 \%$ and a standard deviation of $30 \%$. For the post-1970 sample, haircuts average $39 \%$.

In a related piece, Meyer et al. (forthcoming) offer "rules of thumb" in determining the size of the haircut. There are four key determinants of haircut size: the initial stock of debt (larger the initial stock of a larger, the larger the haircut); per capita income (the poorer the country, the bigger the haircut); the cumulative decline in real GDP between the beginning of the debt crisis and its resolution (the steeper the contraction, the bigger the haircut); duration of the default spell (the longer time it takes, from the beginning of the debt crisis to the resolution, the bigger the haircut). The last of these should, in principle, encourage creditors to expedite the resolution process.

It is noteworthy that even after significant haircuts, Meyer et al. (2019) calculate that real excess ex-post rates of return (over the risk-free rate) on external sovereign debt for their sample is about 3\%. This is not to suggest that the next decade with deliver 3\% excess returns, as there is significant time variation in the two-century sample. In the 1930s and 1980s, two decades with a significant increase in the incidence of sovereign defaults, ex post returns fared poorly.

\subsection{Expediting the Resolution Process}

As discussed, there is little evidence to support the view that private and sometimes official creditors will be willing to accept large losses quickly. So, what can be done to make debt restructuring more expedient? In my recent pieces with Bulow et al. (2020) and Pazarbasioglu and Reinhart (2021), we suggest some possibilities: 


\subsubsection{Realistic Economic Forecasts That Incorporate Downside Risks}

Realistic growth forecasts are critical to avoid underestimating a country's near-term financing needs and overestimating its capacity to service its debt commitments. IMF historian James Boughton (2001) notes that during much of the 1980s debt crisis, over-optimistic growth expectations persisted, especially in Latin America. Realistic forecasts, particularly recognizing the fragility of highly indebted countries, can speed resolution of any crisis. Earlier detection of insolvency and identification of cases in which large write-downs are necessary cannot guarantee a faster resolution but are a step in that direction.

\subsubsection{New Legislation to Support Orderly Sovereign Debt Restructurings}

Legal steps in jurisdictions that govern international bonds (importantly but not exclusively New York and London) or where payments are processed can contribute to more orderly restructuring by promoting a more level playing field between sovereign debtors and creditors. For instance, national legislation can cap the amounts that may be reclaimed from defaulted government bonds bought at a deep discount. In 2010, the United Kingdom enacted such a law for countries taking part in the Heavily Indebted Poor Countries (HIPC) debt relief initiative, while Belgium in 2015 passed the so-called Anti-Vulture Funds Law, which prevents litigious creditors from disrupting payments made via Euroclear. It would also energize legislation to facilitate a majority restructuring, which would allow a sovereign and a qualified majority of creditors to reach an agreement binding on all creditors subject to the restructurings.

\subsubsection{More Transparency on Debt Data and Debt Contracts}

It is of utmost importance that the World Bank, the IMF, and the G20 continue to insist on strengthening the transparency of debt statistics. A new and significant complication in assessing the external indebtedness of many developing economies involves China, which has become the largest bilateral creditor in recent years and lending is often shrouded in nondisclosure clauses. ${ }^{30}$ More granular data on private sector creditor exposure may facilitate, in case of debt distress, more expedient creditor-debtor negotiations and allow both creditors and governments to identify which bonds are at risk of holdout or litigation tactics. An encompassing transparency initiative would include, for instance, full disclosure on sovereign bond ownership as well as credit default swaps that shift lender composition overnight. The accounts for the country itself must become more comprehensive, with improved data on domestic debt and debt owed by state-owned enterprises. Accounting for pension burdens is also increasingly important.

\footnotetext{
${ }^{30}$ See Gelpern et al. (2021), who are the first to analyze the features of China's overseas lending contracts.
} 


\section{Final Reflections}

Extremely accommodative global liquidity conditions mitigate some of the risks discussed. Unlike the 1980s and the 1930s, real ex-post interest rates are close to historic lows. Furthermore, in the major advanced economies, central banks' tolerance for higher interest rates may decline further as levels of public and private debt climb to new highs. Low interest rates have, since time immemorial, encouraged risk-taking and fueled the search for yield. Other things equal, these push-factors may support private flows to EMDEs,

Other things have not been equal. For EMDEs as a class, risk premia have risen, and a record number of sovereigns have been downgraded. Earlier in 2020, El Salvador issued a 30 -year US dollar bond with a $91 / 2 \%$ coupon. Coupons above $8 \%$ have not been uncommon. It will take a great deal of sustained growth to square (the much-discussed) $r-g$ debt sustainability calculus in these cases. ${ }^{31}$

Multilateral institutions may also face their biggest challenge since the 1980s. The crises in the 1990s in Mexico and East Asia were significant but contained. Following the GFC, the size of the IMF programs for Greece, Iceland, Ireland, and Portugal were record-shattering but still focused in a handful of countries. Importantly, those cases also counted with substantive financial support from Europe. The pandemics' damage is much more diffuse and in many cases the financing gaps are likely to prove persistent.

Conglomerate crises are typically associated with deep protracted recessions. Old challenges that have been thought dead or tamed in some EMDEs (i.e., currency instability and higher inflation rates) may resurface. Dealing with conglomerate crises will require an expanded toolkit, an open mind, and an encompassing integrated approach.

The economic downturn, as we're seeing today, leads to collapses in government revenues, the need for further expenditure (fiscal finances deteriorate). Worsening matters is what is beneath the surface, as in the classic Diaz Alejandro paper "Goodbye Financial Repression, Hello Financial Crash." Often, the government sits on a time bomb of contingent liabilities of private debt, that the government, in its efforts to support the banking sector, will end up assuming. We've seen this time and time again.

\section{Declarations}

Conflict of interest On behalf of all authors, the corresponding author states that there is no conflict of interest.

31 Favorable debt dynamics require that the real interest rate on debt, $r$, is less than real growth, $g$ 


\section{References}

Allen, Franklin and Douglas Gale. 2007. Understanding Financial Crises. New York: Oxford University Press.

Asonuma, Tamon and H. Joo. 2020. Sovereign Debt Restructurings: Delays in Renegotiations and Risk Averse Creditors. Journal of the European Economic Association 18(5): 2394-2440.

Asonuma, Tamon and Christoph Trebesch. 2016. Sovereign Debt Restructurings: Preemptive or PostDefault. Journal of European Economic Association 1(1): 175-216.

Barro, Robert J. and Jose Ursua. 2008. Macroeconomic Crises Since 1870. Brookings Papers on Economic Activity Spring 39(1): 255-350.

Barron, Matthew, Emil Verner and Wei Xion. 2021. Banking Crises Without Panics. The Quarterly Journal of Economics 136(1): 51.

Barry, John M. 2009. The Great Influenza: The Story of the Deadliest Pandemic in History. London: Penguin Books.

Beers, David, Elliot Jones, and John Walsh. 2020. BoC-BoE: Sovereign Default Database: What is New in 2020. Staff Analytical Note.

Benjamin, D. and M. Wright. 2009. Recovery Before Redemption: A Theory of Delays in Sovereign Debt Renegotiations.

Bernanke, Ben S. and Harold James. 1991. The Gold Standard, Deflation, and Financial in the Great Depression: An International Comparison. In Financial Markets and Financial Crises, ed. G. Hubbard. Chicago: University of Chicago Press for the NBER.

Bernhard, H., B. Christian, and Karb Volker. 2006. Are twin currency and debt crises special? In Proceedings of the German Development Economics Conference, Berlin 2006 11, Verein für Socialpolitik, Research Committee Development Economics.

Bordo, Michael, Barry Eichengreen, Daniela Klingebiel and Maria Soledad Martinez-Peria. 2001. Is the Crisis Problem Growing More Severe? Economic Policy 16: 51-82.

Bordo, Michael and Christopher Meissner. 2016. Fiscal and Financial Crises. Handbook of Macroeconomics, Vol. 2 (New York: Elsevier), 355-412.

Bosio, Erica, Rita Ramalho, and Carmen M. Reinhart. 2021. The Invisible Burden: How Arrears Could Unleash a Banking Crisis. VoxEU, March 22.

Boughton, James. 2001. Silent Revolution: The International Monetary Fund 1979-1989. Washington, DC: International Monetary Fund.

Broner, Fernando, Guido Lorenzoni and Sergio Schmukler. 2013. Why Do Emerging Economies Borrow Short-Term? Journal of the European Economic Association 11(1): 67-100.

Bruno, Michael and William Easterly. 1998. Inflation Crises and Long-run Growth. Journal of Monetary Economics 41(1): 3-26.

Bryant, John. 1980. A Model of Reserves, Bank Runs and Deposit Insurance. Journal of Banking and Finance 4(4): 335-344.

Bulow, Jeremy, Carmen M. Reinhart, Kenneth Rogoff and Christoph Trebesch. 2020. The Debt Pandemic. Finance and Development 57: 13-16.

Bulow, Jeremy and Kenneth Rogoff. 1989. A Constant Recontracting Model of Sovereign Debt. Journal of Political Economy 97(February): 155-78.

Cagan, Philip. 1956. The Monetary Dynamics of Hyperinflation. In Studies in the Quantity Theory of Money, ed. Milton Friedman. Chicago: University of Chicago Press.

Calice, Pietro, Federico Diaz Kalan, and Oliver Masetti. 2020. Interest Rate Repression: A New Database. Policy Research Working Paper No. 9457, World Bank.

Calvo, Guillermo A. 1998. Capital Flows and Capital-Market Crises: The Simple Economics of Sudden Stops. Journal of Applied Economics 1(1): 35-55.

Calvo, Guillermo and Carmen M. Reinhart. 2000. When Capital Inflows Come to a Sudden Stop: Consequences and Policy Options. In Reforming the International Monetary and Financial System, Peter Kenen and Alexandre Swoboda, editors, 175-201. Washington DC: International Monetary Fund.

Calvo, Guillermo A., Izquierdo, Alejandro, Mejía, Luis-Fernando. 2004. On the Empirics of Sudden Stops: the Relevance of Balance-Sheet Effects. NBER Working Paper No. 10520.

Caprio, Gerald and Daniela Klingebiel. 1996. Bank Insolvency: Bad Luck, Bad Policy, or Bad Banking? In Annual World Bank Conference on Development Economics, ed. B. Pleskovic and J. Stiglitz, 79-104. Washington, DC: The World Bank. 
Chang, Roberto and Andres Velasco. 2000. Liquidity Crises in Emerging Markets. In NBER Macroeconomics Annual 1999, ed. B. Bernanke and J. Rotemberg, vol. 14, 11-78. MIT Press.

Conant, Charles A. 1861-1915. A history of modern banks of issue, with an account of the economic crises of the nineteenth century and the crisis of 1907, (New York London: G. P. Putnam's sons, 1909)

Cruces, Juan and Christoph Trebesch. 2013. Sovereign Defaults: The Price of Haircuts. American Economic Journal: Macroeconomics 5(3): 85-117.

Diamond, Douglas and Philip Dybvig. 1983. Douglas VV. Diamond. The Journal of Political Economy 91(3): 401-419.

Diaz-Alejandro, Carlos. 1985. Good-by Financial Repression, Hello Financial Crash. Journal of Development Economics 19(1-2): 1-24.

Eichengreen, Barry, Andrew Rose and Charles Wyplosz. 1996. Contagious Currency Crises: First Tests. Scandinavian Journal of Economics 98(4): 463-484.

Fang, C., J. Schumacher, and Christoph Trebesch. 2021. Restructuring Sovereign Bonds: Holdouts, Haircuts and the Effectiveness of CACs. IMF Economic Review, forthcoming.

Farah-Yacoub, Juan, Clemens Graf von Luckner, and Carmen M. Reinhart. 2021. The Eternal External Debt Crisis: A Long View on Systemic, Regional, and Idiosyncratic Episodes. World Bank mimeograph, forthcoming.

Fatás, Antonio and Mihov, Ilian. (July 2013). Recoveries. Available at SSRN: https://ssrn.com/abstract= 2294810

Frankel, Jeffrey and Andrew Rose. 1996. Currency Crashes in Emerging Markets. Journal of International Economics 41(3-4): 351-366.

Gelpern, Anna, Sebastian Horn, Scott Morris, Brad Parks, and Christoph Trebesch. 2021. How China Lends: A Rare Look into 100 Debt Contracts with Foreign Governments. Peterson Institute for International Economics, Kiel Institute for the World Economy, Center for Global Development, and AidData at William \& Mary.

Ghosal, S., and M. Miller. 2017. A New Bargaining Perspective on Sovereign Debt Restructuring. VoxEU, April 17.

Gorton, Gary. 2010. Slapped by the Invisible Hand: The Panic of 2007. New York: Oxford University Press.

Graf Von Luckner, Clemens, Josefin Meyer, Carmen M. Reinhart, and Christoph Trebesch. 2021. External Sovereign Debt restructurings: Delay and Replay. Vox EU, March. https://voxeu.org/ article/external-sovereign-debt-restructurings-delay-and-replay

Horn, Sebastian, Carmen M. Reinhart and Christoph Trebesch. 2019. China's Overseas Lending. NBER Working Paper 26050, July 2019.

Ilzetzki, Ethan, Carmen M. Reinhart, Kenneth S. Rogoff. 2019. Exchange Arrangements Entering the Twenty-First Century: Which Anchor will Hold? The Quarterly Journal of Economics 134(2): 599-646.

Kaminsky, Graciela and Carmen M. Reinhart. 1999. The Twin Crises: The Causes of Banking and Balance-of-Payments Problems. American Economic Review 89(3): 473-500.

Kindelberger, Charles. 1978. Manias, Panics, and Crashes: A History of Financial Crises. New York: Basic Books.

Laeven, Luc and Fabian Valencia. 2013. Systemic Banking Crises Database. IMF Economic Review 61: 225-270.

Laeven, Luc, Fabian Valencia. 2020. Systemic Banking Crises Database II. IMF Economic Review 68(2):307-361.

McKinnon, Ronald and Huw Pill. 1996. Credible Liberalizations and International Capital Flows: The "Overborrowing Syndrome. In Financial Deregulation and Integration in East Asia, NBEREASE, ed. T. Ito and A. Krueger, vol. 5, 7-50. Chicago: University of Chicago Press.

Meyer, Josefin, Carmen M. Reinhart, and Christoph Trebesch. 2019. Sovereign Bonds Since Waterloo. NBER Working Paper 25543.

Meyer, Josefin, Carmen M. Reinhart, and Christoph Trebesch. 2022. Sovereign Bonds Since Waterloo, National Bureau of Economic Research, Working Paper 25543, February 2019. Forthcoming, Quarterly Journal of Economics, August 2022.

Pazarbasioglu, Ceyla and Carmen M. Reinhart 2021. Key to Resolving COVID's Global Debt Crunch: Transparency. Bloomberg.

Pitchford, R. and M. Wright. 2012. Holdouts in Sovereign Debt Restructuring: A Theory of Negotiation in a Weak Contractual Environment. The Review of Economic Studies 79(2): 812-837. 
Reinhart, Carmen M. 2010. This Time is Different Chartbook: Country Histories on Debt, Default, and Financial Crises, NBER Working Papers 15815, National Bureau of Economic Research, Inc.

Reinhart, Carmen M. 2018. International Financial Crises. Nobel Symposium on "Money and Banking" May 26-28, 2018, Stockholm.

Reinhart, Carmen. M., Kenneth S. Rogoff and Miguel A. Savastano. 2003. Debt Intolerance. Brookings Papers for Economic Activity 1: 1-74.

Reinhart, Carmen M. and Kenneth S. Rogoff. 2009. This Time It's Different: Eight Centuries of Financial Folly. Princeton: Princeton University Press.

Reinhart, Carmen M. and Kenneth S. Rogoff. 2011a. From Financial Crash to Debt Crisis. American Economic Review 101(5): 1676-1706.

Reinhart, Carmen M. and Kenneth S. Rogoff. 2011b. The Forgotten History of Domestic Debt. Economic Journal, Royal Economic Society 121(552): 319-350.

Reinhart, Carmen M. and Kenneth S. Rogoff. 2014. Recovery from Financial Crises: Evidence from 100 Episodes. American Economic Review 104(5): 50-55.

Reinhart, Carmen M. and Belen Sbrancia. 2015. The Liquidation of Government Debt. Economic Policy 30(82): 291-333.

Reinhart, Carmen M. and Christoph Trebesch. 2016. Sovereign Debt Relief and its Aftermath. Journal of the European Economic Association 14(1): 215-251.

Rojas-Suarez, Liliana. 2002. Rating Banks in Emerging Markets: What Rating Agencies Should Learn from Financial Indicators. In Ratings, Rating Agencies, and the Financial System, ed. Richard Levich, Giovanni Majnoni, and Carmen M. Reinhart. New York: Springer.

Schularick, Moritz and Alan M. Taylor. 2012. Credit Booms Gone Bust: Monetary Policy, Leverage Cycles, and Financial Crises. American Economic Review 102(2): 1029-1061.

Schumacher, J., C. Trebesch and H. Enderlein. 2021. Sovereign Defaults in Court. Journal of International Economics 131: 103388.

Trebesch, C. 2019. Resolving Sovereign Debt Crises: The Role of Political Risk. Oxford Economic Papers 71(2): 421-444.

Velasco, Andres. 1987. Financial crises and balance of payments crises: A simple model of the southern cone experience. Journal of Development Economics 27(1-2): 263-283.

World Bank. 2020a. Poverty and Shared Prosperity 2020: Reversals of Fortune. Washington DC: The World Bank.

World Bank. 2020b. Covid-19 Finance Sector Related Policy Responses. https://datacatalog.worldbank. org/dataset/covid-19-finance-sector-related-policy-responses.

World Bank. 2020c. Covid-19 Debt Service Suspension Initiative. https://www.worldbank.org/en/topic/ debt/brief/covid-19-debt-service-suspension-initiative

Publisher's Note Springer Nature remains neutral with regard to jurisdictional claims in published maps and institutional affiliations.

Carmen M. Reinhart is the Senior Vice President and Chief Economist of the World Bank Group. Assuming this role on June 15, 2020, Reinhart provides thought leadership for the institution at an unprecedented time of crisis. She also manages the Bank's Development Economics Department. Reinhart's areas of expertise are in international finance, and macroeconomics. Her work has helped to inform the understanding of financial crises in both advanced economies and emerging markets. She has published extensively on capital flows, exchange rate policy, banking and sovereign debt crises, and contagion. She comes to this position on public service leave from Harvard Kennedy School where she is the Minos A. Zombanakis Professor of the International Financial System. Previously, she was the Dennis Weatherstone Senior Fellow at the Peterson Institute for International Economics and Professor of Economics and Director of the Center for International Economics at the University of Maryland. During her career, Reinhart has worked in numerous roles to address policy challenges including most recently, the coronavirus pandemic and its economic impact. She serves in the Advisory Panels of the Federal Reserve Bank of New York and the International Monetary Fund. Earlier, she was the Senior Policy Advisor and Deputy Director of the Research Department at the International Monetary Fund and held positions as Chief Economist and Vice President at the investment bank Bear Stearns. Ranked among the top Economists worldwide based on publications and scholarly citations, Reinhart has been listed among Bloomberg 
Markets Most Influential 50 in Finance, Foreign Policy's Top 100 Global Thinkers, and Thomson Reuters' The World's Most Influential Scientific Minds. In 2018 she was awarded the King Juan Carlos Prize in Economics and NABE's Adam Smith Award, among others. Her book (with Kenneth S. Rogoff) entitled This Time is Different: Eight Centuries of Financial Folly has been translated to over 20 languages and won the Paul A. Samuelson Award. She holds a Ph.D. from Columbia University. 